\title{
Rozumienie pojęcia edukacja włączająca przez nauczycieli szkół ogólnodostępnych
}

\begin{abstract}
STRESZCZENIE
Celem niniejszego opracowania jest zaprezentowanie wyników badań dotyczących rozumienia pojęcia edukacja włączająca przez nauczycieli szkół ogólnodostępnych oraz rozpatrzenie, czy edukacja włączająca jest działaniem celowym, zaplanowanym, czy działaniem intuicyjnym, pozornym. Jest to istotny problem, bowiem warunkiem skutecznego prowadzenia edukacji włączającej jest przede wszystkim rozumienie tego pojęcia przez nauczycieli szkół ogólnodostępnych. Brak rozumienia pojęcia edukacja włączająca może rodzić obawy o kształt jej realizacji. Włączanie to nie tylko przyjmowanie uczniów z niepełnosprawnościami do szkół ogólnodostępnych, ale przede wszystkim dostosowanie programu nauczania do indywidualnych możliwości każdego ucznia, to system oceniania uwzględniający możliwości psychofizyczne poszczególnych uczniów oraz organizacja procesu nauczania z wykorzystaniem odpowiednich pomocy dydaktycznych dostosowanych do specjalnych potrzeb edukacyjnych uczniów. Celem badań było poznanie i rozpatrzenie sposobów rozumienia pojęcia edukacja włączająca przez nauczycieli szkół ogólnodostępnych. W badaniach wykorzystano metodę sondażu diagnostycznego z użyciem techniki ankiety. Otrzymane wyniki badań pokazują, że edukacja włączająca nadal jest pojęciem, które wymaga doprecyzowania i propagowania wśród nauczycieli. Pomimo swojej obecności zarówno w literaturze przedmiotu, jak i w praktyce edukacyjnej nadal budzi niezrozumienie, co utrudnia pełną realizację tego modelu nauczania.
\end{abstract}

1 Beata Skotnicka, Wydział Etnologii i Nauk o Edukacji w Cieszynie, Uniwersytet Śląski w Katowicach, Polska, e-mail: beata_skotnicka@wp.pl, ORCID ID: https://orcid.org/0000-00017700-9810. 


\title{
Słowa kluczowe:
}

edukacja włączająca, nauczyciel, szkoła ogólnodostępna, uczeń z niepełnosprawnością, specjalne potrzeby edukacyjne

\begin{abstract}
The aim of this study is to present the results of research on the understanding of the concept of inclusive education by teachers of mainstream schools and consideration of whether inclusive education is intentional, planned, or intuitive, apparent. This is a significant problem, as the condition for effective implementation of inclusive education is, above all, the understanding of this concept by teachers of public schools. A lack of understanding of the concept of inclusive education may give rise to concerns about the shape of its implementation. Inclusion is not only about accepting students with disabilities in mass schools, but above all, adapting the curriculum to the individual capabilities of each student, a rating system that takes into account the psychophysical capabilities of individual students and the organization of the teaching process using appropriate teaching aids adapted to the students' special educational needs. The aim of the research was to get to know and consider ways of understanding the concept of inclusive education by teachers of generally accessible rural schools. The research used the method of a diagnostic survey using the questionnaire technique. The obtained research results show that inclusive education is still a concept that needs to be clarified and promoted among teachers. Despite its presence both in the literature of the subject and in educational practice, it still raises a misunderstanding, which hinders the full implementation of this teaching model.
\end{abstract}

\section{Keywords:}

inclusive education, teacher, public school, student with disabilities, special educational needs

\section{WPROWADZENIE}

Zagadnienie edukacji włączającej jest obecne w Polsce zarówno w praktyce edukacyjnej, jak i w aktach prawnych od początku lat 90. XX wieku i wydawać by się mogło, że zasady i wzorce postępowania i wdrażania idei edukacji włączającej w praktyce pedagogicznej są znane wszystkim jej uczestnikom, a w szczególności nauczycielom, którzy są realizatorami tego modelu kształcenia. 
Włączanie to złożony proces przebiegający na wielu płaszczyznach życia społecznego. Warunkiem jego realizacji jest rozumienie zagadnienia oraz jego istoty. Tylko wtedy możemy mówić o efektywnym przebiegu edukacji włączającej, gdy wszyscy nauczyciele będą znali jej zasady i postępowali w sposób zgodny z jej założeniami. Jeżeli dobrze zrozumiemy i zaplanujemy proces edukacji włączającej, to przyniesie on korzyści nie tylko uczniom z niepełnosprawnościami, ale także uczniom o prawidłowym rozwoju.

W praktyce edukacyjnej osiągnięcie zamierzonych celów edukacji włączającej może być niemożliwe lub poważnie ograniczone bez zrozumienia jej celu, zasad i organizacji właściwej pomocy psychologiczno-pedagogicznej, zindywidualizowanej pod kątem potrzeb i możliwości każdego ucznia. Toteż celem niniejszego opracowania jest zaprezentowanie wyników badań dotyczących rozumienia pojęcia edukacja włączająca przez nauczycieli szkół ogólnodostępnych. Celem dodatkowym jest rozpatrzenie, czy edukacja włączająca jest działaniem celowym, zaplanowanym, czy działaniem intuicyjnym, pozornym.

Zarówno postawiony cel badań, jak i przyjęte przeze mnie stanowisko pozwalają rozwinąć tezę, że warunkiem skutecznego prowadzenia edukacji włączającej jest przede wszystkim rozumienie tego pojęcia przez nauczycieli szkół ogólnodostępnych, w których realizowany jest opisywany model kształcenia.

\section{EDUKACJA WŁĄCZAJĄCA - USTALENIA TERMINOLOGICZNE}

Przełom XX i XXI wieku to czas ratyfikacji przez Polskę najważniejszych umów, konwencji i porozumień promujących włączający model kształcenia. Dokumentem uważanym za przełomowy dla upowszechniania edukacji włączającej jest Deklaracja z Salamanki oraz Indeks dla Inkluzji. Jednym z ważniejszych momentów było również ratyfikowanie przez Polskę 6 września 2012 roku Konwencji ONZ o prawach osób niepełnosprawnych. Celem polityki oświatowej państwa stało się wprowadzenie włączającego modelu kształcenia, które jest już nie tylko dobrą wolą decydentów, ale ich obowiązkiem.

Zgodnie z art. 24 Konwencji (2012) w celu realizacji prawa osób niepełnosprawnych do edukacji państwa zapewniają im dostęp do włączającego nauczania wysokiej jakości. Oznacza to odejście od segregacyjnego modelu kształcenia na rzecz edukacji włączającej. Działania Polski dążą do promowania edukacji włączającej prowadzonej w szkołach rejonowych, położonych jak najbliżej miejsca zamieszkania, w środowisku życia ucznia. To zadanie długofalowe i złożone, które wymaga zaangażowania wszystkich uczestników życia społecznego w danym 
środowisku. Włączanie dzieci do szkół ogólnodostępnych powinno odbywać się w sposób odpowiedzialny. Jest to proces, który nie odbywa się automatycznie poprzez sam fakt bycia takiego dziecka w szkole (Grabowska, Gębicka-Zdanewicz, 2010). Zdaniem Joanny Głodkowskiej (2010) włączanie można rozumieć jako celowy, systematyczny, zorganizowany proces społeczny, który daje osobom z niepełnosprawnością szanse na życie w jak najmniej ograniczającym środowisku. Włączanie dotyczy różnych aspektów życia społecznego, w tym również edukacji. W ujęciu Głodkowskiej edukację włączającą można postrzegać na trzech poziomach: środowiska lokalnego, placówki edukacyjnej oraz ucznia ze specjalnymi potrzebami edukacyjnymi. Na wymienionych poziomach edukacja włączająca jest definiowana w następujący sposób:

1. Na poziomie otwartego środowiska społecznego włączanie oznacza proces zapewnienia uczniowi ze specjalnymi potrzebami edukacyjnymi możliwości spełniania zadań rozwojowych, funkcjonowania w większej społeczności i poczucia przynależności do niej.

2. Na poziomie systemu edukacyjnego to strategia zapewnienia uczniom ze specjalnymi potrzebami edukacyjnymi dostępu do szkół ogólnodostępnych jak najbliżej miejsca zamieszkania i środowiska jak najmniej ograniczającego rozwój ucznia.

3. Na poziomie konkretnych działań edukacyjnych edukacja włączająca to proces wspólnego kształcenia uczniów ze specjalnymi potrzebami edukacyjnymi z ich sprawnymi rówieśnikami przy zapewnieniu poczucia przynależności i wsparcia wynikającego z niepełnosprawności.

W procesie edukacji włączającej czynny udział biorą nie tylko uczniowie ze specjalnymi potrzebami edukacyjnymi ale również ich nauczyciele, rówieśnicy, rodzice, specjaliści oraz środowisko lokalne.

Pojęcie edukacji włączającej bywa czasami utożsamiane z pojęciem integracji. Viktor Lechta (2010) zwraca jednak uwagę na różnice pomiędzy wymienionymi pojęciami. Zdaniem Lechty pojęcie integracja jest przede wszystkim związane z pojęciem ,tolerancja”, natomiast „inkluzja” wiąże się przede wszystkim z ,akceptacją”. Podobne stanowisko prezentują M. John i P. Baylis (2002), według których „włączanie jest czymś więcej niż integracją”, gdyż gwarantuje równouprawnienie uczniom ze specjalnymi potrzebami edukacyjnymi. Zdaniem wymienionych autorów wprowadzenie edukacji włączającej jest wyrazem przestrzegania praw jednostki ludzkiej. Edukacja włączająca to proces polegający na zwiększaniu uczestnictwa wszystkich uczniów w życiu szkoły, w tym także uczniów o specjalnych potrzebach edukacyjnych. Proces ten polega na zrestrukturyzowaniu szkoły tak, aby odpowiadała na potrzeby wszystkich uczestników edukacji. 
Zdaniem Grzegorza Szumskiego (2010) różnica pomiędzy integracją a inkluzją polega na tym, że idea edukacji włączającej opiera się na społecznym modelu niepełnosprawności, zgodnie z którym to nie ucznia należy zmieniać i przystosowywać do systemu szkolnego, lecz odwrotnie, to szkoła i system nauczania powinien zmienić się tak, by zapewnić realizację indywidualnych potrzeb wszystkich uczniów, zarówno tych niepełnosprawnych, jak i sprawnych. Natomiast integracja opiera się na medycznym modelu niepełnosprawności, skupionym na deficytach dziecka, według którego trzeba przystosować ucznia do warunków szkoły poprzez rehabilitację oraz do istniejących warunków systemu społecznego. Podsumowując, można stwierdzić, że integracja wymaga większego przystosowania ucznia do szkoły, podczas gdy celem edukacji włączającej jest dostosowanie środowiska edukacyjnego do potrzeb ucznia. W opinii Teresy Żółkowskiej (2009, s. 46) „włączanie nie oznacza jedynie umieszczania dzieci z potrzebami specjalnymi w placówkach ogólnodostępnych, ale zakłada konieczność takich zmian w szkołach, aby ich oferta lepiej odpowiadała potrzebom wszystkich uczniów i umożliwiała budowanie systemu wsparcia, który pozwoli im na funkcjonowanie w środowisku naturalnym”. Danuta Al-Khamisy (2013, s. 52) dodaje, że „termin edukacja włączająca nie dotyczy już tylko uczniów ze specjalnymi potrzebami edukacyjnymi, ale obejmuje znacznie szerszą grupę dzieci i młodzieży narażonych na wykluczenie. Ponadto wysoka jakość oferty edukacyjnej dla tych uczniów w szkołach rejonowych musi też gwarantować wysoką jakość oferty dla wszystkich uczniów”.

Zaprezentowane rozważania pozwalają zatem na rozumienie edukacji włączającej jako procesu kształcenia uczniów ze specjalnymi potrzebami edukacyjnymi w szkole ogólnodostępnej, położonej jak najbliżej miejsca zamieszkania, wspólnie z ich sprawnymi rówieśnikami. Zapewnienie poczucia przynależności do społeczności szkolnej oraz zapewnienie wsparcia, środków dydaktycznych, dostosowanie treści nauczania do indywidualnych potrzeb i możliwości rozwojowych wszystkich uczniów oraz przygotowanie ich do pełnego uczestnictwa w życiu społecznym jako pełnoprawnych członków społeczeństwa.

\section{KONCEPCJA BADAŃ WŁASNYCH}

Głównym celem badań było poznanie i rozpatrzenie sposobów rozumienia pojęcia edukacja włączająca przez nauczycieli szkół ogólnodostępnych. Celem dodatkowym było rozpatrzenie, czy edukacja włączająca jest działaniem celowym, zaplanowanym, czy działaniem intuicyjnym, pozornym. Przedmiotem badań były deklaracje nauczycieli szkół ogólnodostępnych dotyczące rozumienia pojęcia 
edukacja włączająca. Główny problem badawczy został zawarty w pytaniu:

Jak jest rozumiane pojęcie edukacja włączająca przez nauczycieli szkół ogólnodostępnych?

Istotnym dopełnieniem problemu głównego są pytania:

1. Jaki jest związek pomiędzy rozumieniem pojęcia edukacja włączająca przez nauczycieli szkół ogólnodostępnych a ich postawami wobec tego typu kształcenia?

2. Jaki jest związek pomiędzy rozumieniem pojęcia edukacja włączająca przez nauczycieli szkół ogólnodostępnych a ich kwalifikacjami w zakresie pedagogiki specjalnej?

W celu uzyskania odpowiedzi na postawione pytania badawcze wykorzystano metodę sondażu diagnostycznego z użyciem techniki ankiety. Badania przeprowadzono w 29 szkołach ogólnodostępnych powiatu bydgoskiego. W badaniach uczestniczyło 145 nauczycieli pracujących w tych szkołach. Staż pracy nauczycieli był zróżnicowany i wynosił od 2 do 35 lat. Nauczyciele posiadali następujące stopnie awansu zawodowego: nauczyciel stażysta 3 osoby, nauczyciel mianowany 34 osoby, nauczyciel kontraktowy 17 osób i nauczyciel dyplomowany 91 osób.

\section{ROZUMIENIE POJĘCIA EDUKACJA WŁĄCZAJĄCA PRZEZ NAUCZYCIELI SZKÓŁ OGÓLNODOSTĘPNYCH}

Rozumienie pojęcia edukacja włączająca stanowi podstawowy warunek jej właściwej i skutecznej realizacji. Wiedza na temat inkluzji i pracy z uczniem z niepełnosprawnościami w warunkach szkoły ogólnodostępnej wiąże się ze znajomością specjalnych potrzeb edukacyjnych tego ucznia. Z analizy zgromadzonych danych wynika, że ponad połowa badanych nauczycieli (59\%) właściwie interpretowała określenie edukacja włączająca, co pozwala stwierdzić, że ta grupa badanych rozumie pojecie, istotę i zasady realizacji edukacji włączające (z uwagi na ograniczoną objętość niniejszego artykułu nie przytaczam poprawnych odpowiedzi). Spośród osób zaliczonych do tej grupy 12\% respondentów rozumiało to pojecie częściowo. W odpowiedziach badanych dominowały określenia i porównania do edukacji integracyjnej. Edukacja włączająca to: „tworzenie klas integracyjnych”, „nauczanie integracyjne, czyli w grupie zwykłych rówieśników”, oraz skupiono się głównie na pracy z uczniem w klasie: „włączanie dzieci objętych nauczaniem indywidualnym w zajęcia w grupie szkolnej”, „prowadzenie zajęć w taki sposób, by dziecko z SPE było w nie włączone”, ,edukacja włączająca włącza dziecko do życia klasy”, z pominięciem szerszego kontekstu edukacji włączającej, a miano- 
wicie środowiska rówieśniczego, szkolnego oraz środowiska lokalnego.

Kolejną kategorię stanowiły odpowiedzi świadczące o braku znajomości pojęcia edukacja włączająca przez badanych nauczycieli. 10\% badanych nauczycieli nie potrafiło określić właściwie, na czym polega edukacja włączająca. Nauczyciele wskazywali to w sposób bezpośredni:

„nie wiem”, „nie rozumiem pojęcia”, „nie spotkałam się z tym pojęciem” bądź udzielali odpowiedzi świadczących o kompletnej nieznajomości zagadnienia: „jest dokładnie tym, czym ona jest”, „to edukacja w różnych dziedzinach”, „usprawnianie dysfunkcji”, „włączanie wszystkich nauczycieli w nauczanie uczniów niepełnosprawnych”, „edukacja włączająca wszystkie zmysły w nauczaniu”.

Zastanawiający jest fakt, że 19\% badanych nauczycieli nie udzieliło w ogóle odpowiedzi na to pytanie. Brak odpowiedzi uznałam za brak wiedzy w tym zakresie. Łącząc kategorię „nie rozumie” z kategorią „brak odpowiedzi”, uznaną przeze mnie za zakamuflowany brak wiedzy, otrzymałam niepokojąco wysoki wynik odpowiedzi negatywnych - 29\%.

W wyniku przeprowadzonych analiz okazało się, że blisko 1/3 badanych nauczycieli szkół ogólnodostępnych nie rozumiało pojęcia edukacja włączająca, pomimo że realizuje ten model kształcenia. W przypadku tej grupy badanych trudno mówić o planowanym, świadomym procesie realizacji edukacji włączającej. Można domniemywać, że w odniesieniu do tej grupy nauczycieli zachodzi realne ryzyko prowadzenia edukacji w sposób intuicyjny, pozbawiony metodycznych i merytorycznych podstaw. Takie działania można zatem uznać za pozorne.

W ujęcia Słownika języka polskiego pozorny to „taki, który sprawia wrażenie prawdziwego, ale nim nie jest” (Doroszewski, 1985). Według Jana Lutyńskiego (1990a, s. 106) „działania pozorne to czynności, które nie realizują swoich bezpośrednich celów, mimo iż powinny być realizowane zgodnie z wyobrażeniami w danej kulturze czy społeczeństwie”.

W koncepcji Lutyńskiego (1990a) działania pozorne mają sześć podstawowych cech:

- oficjalnie uznaje się je za istotne dla realizacji, niekoniecznie samodzielnej, jakiegoś ważnego społecznie celu,

- celu tego faktycznie nie realizują bądź nie przyczyniają się do jego realizacji,

- o nieprzydatności tego rodzaju działań wiedzą wszyscy lub prawie wszyscy w danej zbiorowości czy społecznym systemie, 
- jest to wiedza prywatna, nie jest ona publicznie, zwłaszcza oficjalnie, uzewnętrzniana,

- wystarczającą, choć nie zawsze jedyną, racją ich występowania w jakiejkolwiek postaci jest to, że przypisano im istotną rolę w realizacji danego celu, ich rzeczywista funkcja polega więc zawsze - co nie znaczy wyłącznie - na ich istnieniu, przy czym może być to również istnienie w postaci szczątkowej, jedynie formalnie,

- działaniom pozornym można przypisać element fikcji, który odnosi się do przebiegu działań lub celu.

Zdaniem Lutyńskiego (1990a, s. 116) niezależnie od różnic między rodzajami czy typami działań pozornych u podłoża wszystkich znajduje się ,„[...] zawsze jakaś niespójność, brak zgodności, przede wszystkim brak zgodności między tym, co się głosi lub zakłada, a tym, co rzeczywiście się realizuje”.

O działaniach pozornych wspomina również Maria Dudzikowa (2013), która pokazuje ich przejawy w wybranych aspektach praktyki edukacyjnej. Dudzikowa, wykorzystując metaforę Lutyńskiego, opisuje działania pozorne w edukacji jako pracę „na jałowym biegu”, demaskując działania tylko z pozoru podejmowane w trosce o dobro dzieci i młodzieży, tj. wprowadzenie egzaminów i ogólną „testomanię”, tłumaczone koniecznością zapewnienia odpowiednio wysokiej jakości edukacji. Jak podkreśla wspomniana autorka (Dudzikowa, 2013, s. 53), pozorność tych działań polega na tym, że „władza wmontowała głoszenie wartości powszechnie uznawanych (tu wspieranie rozwoju ucznia) i podnoszenie waloru efektywności sprawnego działania w racje przymusu realizowania w szkołach podjętej przez siebie decyzji”. Odwołując się do badań Marii Groenwald, Dudzikowa (2013, s. 167) stwierdza, że takie działania stanowią swoisty parawan, bowiem „ostatecznie kształcenie w szkole staje się nie tyle wspieraniem ucznia, ile raczej jego urabianiem od najwcześniejszych lat tak, jak chcą tego instytucje kierujące egzaminami i oświatą oraz jak chcą tego ugrupowania i siły nimi zarządzające”. Pozorność działań sprawia, że mamy do czynienia z „,mitem o szkole jako miejscu wszechstronnego rozwoju ucznia”2.

Brak rozumienia pojęcia edukacja włączająca może przyczynić się do tego, że działania nauczycieli związane z realizacją tego modelu kształcenia będą działaniami pozornymi, które celu tego faktycznie nie realizują bądź nie przyczyniają się do jego realizacji. Jak wspomniałam na wstępie, inkluzja to nie tylko przyjmowanie uczniów z niepełnosprawnościami do szkół masowych, ale przede

2 Określenie wprowadzone przez Marię Dudzikową (2001). 
wszystkim dostosowanie programu nauczania do indywidualnych możliwości każdego ucznia, to system oceniania uwzględniający możliwości psychofizyczne poszczególnych uczniów oraz organizacja procesu nauczania z wykorzystaniem odpowiednich pomocy dydaktycznych dostosowanych do specjalnych potrzeb edukacyjnych uczniów. Edukacja włączająca to również budowanie poczucia wspólnoty wszystkich uczestników edukacji, wspólna praca i zabawa oraz pełna akceptacja wszystkich uczniów. W związku z tym, że pełnoprawnymi uczestnikami edukacji włączającej w szkole ogólnodostępnej są również uczniowie z niepełnosprawnościami, nauczyciele powinni posiadać gruntowną wiedzę na temat niepełnosprawności, umiejętności diagnozowania potrzeb i możliwości ucznia w celu dostosowania metod pracy do jego możliwości psychofizycznych, tak aby wykorzystać w pełni potencjał każdego ucznia. Brak znajomości zasad edukacji włączającej sprawia, że działania podejmowane przez nauczycieli nie będą w pełni spełniać swoich funkcji, ponieważ „poświęcając czas na działania pozorne, nie mogą go przecież zużyć na pracę autentyczną tworzącą wartości i zaspokajającą ludzkie potrzeby” (Lutyński, 1990b, s. 170), w tym przypadku potrzeby uczniów z niepełnosprawnościami.

\section{POSTAWY NAUCZYCIELI OGÓLNODOSTĘPNYCH SZKÓ Ł WIEJSKICH WOBEC EDUKACJI WŁĄCZAJĄCEJ}

Postawa jest konstruktem złożonym, w którym można wyodrębnić kilka elementów składowych, tj. „,wiedza o przedmiocie postawy, stosunek emocjonalny do tego przedmiotu oraz doświadczenia i gotowość do określonych zachowań wiążących się z tym przedmiotem” (Chodkowska, Kazanowski, 2007, s. 12). Ta wielowarstwowość pojęcia postawy sprawia, że zagadnienie związane z funkcjonowaniem i badaniem postaw jest zadaniem złożonym. W literaturze przedmiotu autorzy zwracają uwagę na różne ujęcia tego pojęcia. W ujęciu Słownika języka polskiego postawa to „stosunek człowieka do życia lub do pewnej wyróżnionej sfery zjawisk; ustosunkowanie się do czegoś, czyjeś nastawienie, stanowisko, poglądy” (Szymczak, 1987, s. 807). Dla Stanisława Miki (1987, s. 116) postawa to „względnie trwała struktura (lub dyspozycja do pojawienia się takiej struktury) procesów poznawczych, emocjonalnych i tendencji do zachowań, w której wyraża się określony stosunek do danego przedmiotu”. W literaturze socjologicznej natomiast odnajdujemy dwojakie rozumienie pojęcia postawy, a mianowicie jako definicję sytuacji, jakiej dokonuje człowiek, podejmując interakcję w kierunku sprecyzowanej osoby jako partnera interakcji, lub jako element osobowości, ro- 
zumiany jako gotowość człowieka do określonego zachowania wobec przedmiotu postawy (Turowski, 2001, s. 44-45).

Maria Chodkowska i Zdzisław Kazanowski (2007, s. 14) zauważają, że „złożoność problematyki postaw odkrywamy zwłaszcza w sytuacji, gdy przedmiot postawy jest niejednoznacznie rozumiany, a z taką właśnie kwestią mamy do czynienia w przypadku niepełnosprawności”. W tym przypadku postawa może być przyjmowana wobec trzech zakresów przedmiotu, a mianowicie: wobec samej niepełnosprawności, osoby z niepełnosprawnością i integracji osób niepełnosprawnych. Analogicznie do wspomnianych autorów - w prowadzonych przeze mnie badaniach deklarowane przez nauczycieli postawy wobec edukacji włączającej to postawy wobec niepełnosprawności, osób niepełnosprawnych objętych włączaniem oraz wobec włączania uczniów z niepełnosprawnościami do szkoły ogólnodostępnej.

Kolejnym zagadnieniem, na które chciałabym zwrócić uwagę, jest kwestia postaw deklarowanych versus rzeczywistych. Amadeusz Krause (2010, s. 56) problem ten określa mianem „subtelnej marginalizacji”, a Zenon Gajdzica (2013, s. 23-24) traktuje to bardziej bezpośrednio, pisząc o „nieszczerych deklaracjach”, które mogą być wynikiem tak zwanej poprawności politycznej, presji grupy lub przekonania, że przyniosą indywidualne korzyści.

Analiza przeprowadzonych badań pozwoliła na określenie, że ponad połowa, (58\%) badanych nauczycieli deklarowała pozytywną postawę wobec edukacji włączającej. 34\% badanych deklarowało postawę ambiwalentną, a tylko 8\% wyraziło postawę negatywną. Wysoki odsetek osób deklarujących pozytywne nastawienie do wspólnej edukacji uczniów niepełnosprawnych z ich sprawnymi rówieśnikami stanowi potwierdzenie, że „akceptacja osoby z niepełnosprawnością wynika jednoznacznie z akceptacji osoby ludzkiej jako takiej, co stanowi podstawę nie tylko humanizmu, ale również harmonijnej organizacji życia społecznego” (Chodkowska, Kazanowski, 2007, s. 15). Postawa ta jest również tożsama z założeniami inkluzji, która zakłada akceptację różnorodności i poszanowanie indywidualnych potrzeb i możliwości wszystkich uczestników edukacji. Co trzeci respondent deklarował ambiwalentną postawę wobec wspólnej edukacji uczniów niepełnosprawnych w środowisku szkoły ogólnodostępnej. Ambiwalencja wobec integracji - zdaniem Chodkowskiej i Kazanowskiego (2007, s. 17), to brak dążenia do zespalania się poprzez bycie razem w znaczeniu zarówno fizycznym, jak i psychospołecznym, a tym samym wyrażanie nastawień segregacyjnych. Niepokojący moim zdaniem jest fakt, że łącząc postawy negatywne z ambiwalentnymi otrzymano łącznie 42\% nauczycieli prezentujących nieprzychylną postawę wobec edukacji włączającej, co w dobie promowania tegoż modelu kształcenia nie napawa 
optymizmem. Podobne wyniki odnotowali w swoich badaniach M. Chodkowska i Z. Kazanowski (2007, s. 230), którzy analizowali postawy nauczycieli wobec integracji szkolnej dzieci niepełnosprawnych. Z danych zebranych podczas ich badań wynika, że 30,9\% badanych cechowało się wysokim nasileniem postawy wobec wspólnego kształcenia uczniów pełno- i niepełnosprawnych. Przeciętne nasilenie wykazywało 42,8\% badanych, natomiast co czwarty badany (26,9\%) cechował się najniższym nasileniem postawy, co zdaniem autorów oznacza brak akceptacji dla tej formy edukacyjnej. Odmienne wyniki prezentuje Zenon Gajdzica (2011) badający opinie nauczycieli szkół ogólnodostępnych na temat edukacji włączającej uczniów z niepełnosprawnością intelektualną w stopniu lekkim. Badani nauczyciele w zdecydowanej większości (85\%) deklarowali swój sprzeciw wobec kształcenia uczniów z lekką niepełnosprawnością intelektualną w szkole ogólnodostępnej. Grupę tę stanowili zdecydowani i umiarkowani przeciwnicy. Zdecydowaną mniejszość (12\%) stanowili zdecydowani i umiarkowani zwolennicy. Zdaniem Gajdzicy (2011, s. 78) deklaracje przedstawiające negatywne postawy nauczycieli wobec edukacji uczniów z niepełnosprawnością intelektualną w szkole ogólnodostępnej stanowią bodajże najważniejszą barierę edukacji włączającej. Potwierdzają to również badania Beaty Jachimczak (2008) dotyczące gotowości nauczycieli szkół ogólnodostępnych do pracy z uczniami o specjalnych potrzebach edukacyjnych. Badania nad postawami nauczycieli szkół ogólnodostępnych, integracyjnych i specjalnych wobec wspólnego kształcenia uczniów z różnymi rodzajami niepełnosprawności z ich pełnosprawnymi rówieśnikami (w placówkach ogólnodostępnych lub integracyjnych) przeprowadziły również Katarzyna Ćwirynkało i Agnieszka Żyta (2015). Dane uzyskane przez wspomniane autorki wskazują na największą otwartość na wspólną edukację uczniów pełno- i niepełnosprawnych wśród nauczycieli szkół integracyjnych i stosunkowo mniejszą wśród nauczycieli szkół specjalnych i ogólnodostępnych. Autorki zauważają, że częściej zdarzało się, że najmniej przechylnie do wspólnego kształcenia obu grup uczniów nastawieni byli nauczyciele szkół specjalnych. W badaniach zauważono, że istotny wpływ na pozytywne postawy wobec wspólnego kształcenia mają wcześniejsze doświadczenia nauczycieli w pracy z uczniami z danym rodzajem niepełnosprawności (2015, s. 256).

Podsumowując, podzielam stanowisko wyrażone przez Chodkowską i Kazanowskiego (2007, s. 17), według których „postawa wobec osoby z niepełnosprawnością jest tożsama wobec jej integracji” (w przypadku moich badań inkluzji). Wspomniani autorzy zwracają uwagę na to, że jeżeli akceptujemy osobę, to przyznajemy jej tym samym prawo do bycia we wspólnej przestrzeni, w tym przypadku przestrzeni klasy i szkoły ogólnodostępnej. Konkludując - pozytywna 
postawa wobec edukacji włączającej to akceptacja różnorodności, gwarantująca pełnoprawne uczestnictwo w różnych aspektach życia społecznego na równi z innymi jej uczestnikami.

W dalszej części badań określono zależność pomiędzy rozumieniem pojęcia edukacja włączająca przez nauczycieli szkół ogólnodostępnych a ich postawami wobec tego typu kształcenia. Zobrazowanie wyników badań stanowi wykres 1.

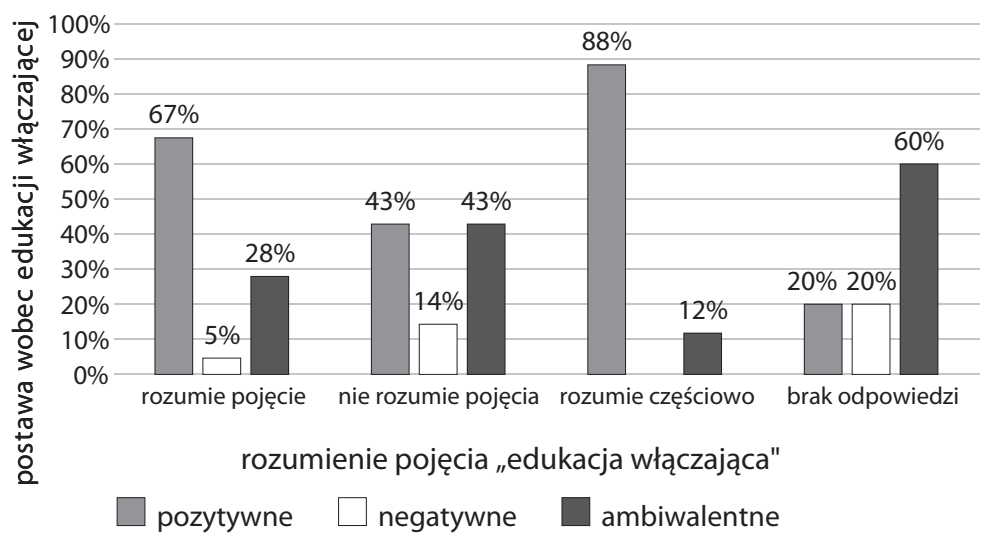

$$
(\mathrm{N}=145) \mathrm{C}=0,402 ; \mathrm{p}<0,05 \mathrm{i}
$$

Wykres 1. Rozumienie pojęcia edukacja włączająca a postawa wobec edukacji włączającej

Źródło: Opracowanie własne na podstawie przeprowadzonych badań

Analiza danych wykazała, że współczynnik kontyngencji C=0,4 przy poziomie istotności $\mathrm{p}<0,05$, oznacza to, że zależność jest istotna statystycznie, a siła związku jest na poziomie umiarkowanym. Wśród nauczycieli, którzy rozumieli pojęcie edukacja włączająca, ponad połowa deklarowała pozytywną postawę wobec edukacji włączającej. Jeszcze wyższy odsetek nauczycieli deklarujących postawę pozytywną zanotowano wśród nauczycieli, którzy częściowo rozumieli pojęcie edukacja włączająca (88\%). Natomiast podobny odsetek nauczycieli, którzy nie rozumieli pojęcia edukacja włączająca i tych, którzy nie udzielili odpowiedzi na to pytanie (14\% i 20\%), wskazało negatywne nastawienie do edukacji włączającej. Zatem na podstawie analizy wyników badań można wnioskować, że nauczyciele rozumiejący pojęcie edukacja włączająca częściej są do niej nastawieni pozytywnie. Potwierdzają to w swoich badaniach Barbara Skałbania i Mirosław Babiarz (2018), którzy stwierdzają, że pierwszym istotnym zagrożeniem dla realizacji idei edukacji włączającej są negatywne postawy nauczycieli wobec wspólnego kształ- 
cenia uczniów niepełnosprawnych i pełnosprawnych, co zdaniem wspomnianych autorów wiąże się z niezrozumieniem przez nich idei inkluzji oraz brakiem wiedzy na temat potrzeb dziecka z niepełnosprawnością.

\section{KWALIFIKACJE NAUCZYCIELI OGÓLNODOSTĘPNYCH SZKÓŁ WIEJSKICH W ZAKRESIE PEDAGOGIKI SPECJALNEJ}

Realizacja edukacji włączającej obok znajomości jej zasad i pozytywnych postaw nauczycieli wobec tego typu kształcenia wymaga również wiedzy na temat niepełnosprawności, ponieważ włączanie dotyczy min. sporej grupy uczniów ze specjalnymi potrzebami edukacyjnymi, wśród których wiodącą kategorię stanowią uczniowie z niepełnosprawnościami. Toteż niezwykle ważną rolę w procesie włączania tych uczniów we wspólny nurt kształcenia odgrywa nauczyciel posiadający odpowiednie kompetencje do pracy z uczniami ze specjalnymi potrzebami edukacyjnymi. Jego wiedza i umiejętności diagnostyczne, metodyczne, terapeutyczne są niezbędne do udzielania profesjonalnego wsparcia uczniom z niepełnosprawnościami w środowisku szkoły ogólnodostępnej. Równie istotnym elementem przygotowania nauczycieli do pracy w klasie o zróżnicowanym poziomie potrzeb i możliwości jest wiedza z zakresu pedagogiki specjalnej, dotycząca sposobów dostosowania warunków nauczania do indywidualnych potrzeb i możliwości każdego ucznia (Skotnicka, 2017, s. 77). Kolejnym etapem badań było zatem sprawdzenie korelacji pomiędzy rozumieniem pojęcia edukacja włączająca a kwalifikacjami nauczycieli z zakresu pedagogiki specjalnej. Zobrazowanie tej zależności przedstawia wykres 2.

Z deklaracji nauczycieli wynika, że ponad połowa (52\%) badanych posiadała kwalifikacje z zakresu pedagogiki specjalnej uzyskane podczas studiów licencjackich na kierunku pedagogika specjalna, studiów podyplomowych z oligofrenopedagogiki, surdopedagogiki oraz kursów kwalifikacyjnych z oligofrenopedagogiki. Natomiast 48\% nauczycieli deklarowało brak takich kwalifikacji. Wysoki odsetek nauczycieli posiadających kwalifikacje z zakresu pedagogiki specjalnej może być wynikiem ich przygotowania do realizacji edukacji włączającej i chęci podnoszenia swoich kwalifikacji w celu zapewnienia uczniom ze specjalnymi potrzebami edukacyjnymi wysokiego poziomu wsparcia i dostosowania programów nauczania do ich specjalnych potrzeb, wynikających z niepełnosprawności bądź uwarunkowanych innymi przyczynami. Wiedza o poszczególnych rodzajach niepełnosprawności może pomóc nauczycielom zrozumieć ograniczenia uczniów wynikające z ich deficytów oraz zrozumieć ich potrzeby w zakresie dostosowania działań wspierających zarówno w nauce, jak i codziennym uczestnictwie w życiu klasy i szkoły, 


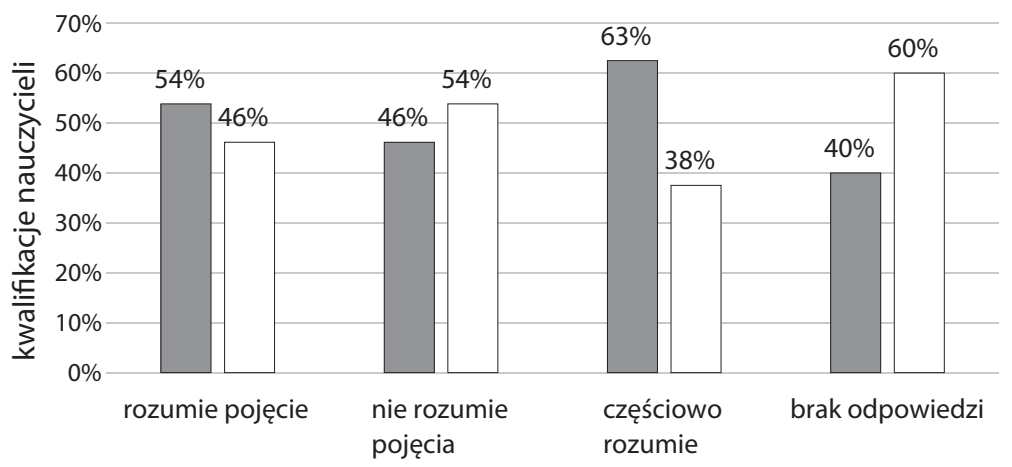

rozumienie pojęcia „edukacja włączająca"

posiada kwalifikacje nie posaiada kwalifikacji

$(\mathrm{N}=145) \mathrm{C}=0,1 ; \mathrm{p}>0,05 \mathrm{ni}$

Wykres 2. Kwalifikacje nauczycieli a rozumienie pojęcia edukacja włączająca Źródło: Opracowanie własne na podstawie przeprowadzonych badań

co pozwoli na dostosowanie programów nauczania, środków dydaktycznych oraz pełne włączenie każdego ucznia do społeczności szkoły ogólnodostępnej. Nie potwierdzają tego badania przeprowadzone przez Zenona Gajdzicę (2011), który stwierdza, że połowa badanych nauczycieli posiadających kwalifikacje z zakresu pedagogiki specjalnej deklaruje brak przygotowania do pracy z uczniem o zaburzonym rozwoju. 22\% uważa, że jest przygotowana, natomiast tylko $4 \%$ badanych nauczycieli posiadających kwalifikacje z pedagogiki specjalnej zadeklarowało dobre przygotowanie do pracy z uczniem niepełnosprawnym.

Przeprowadzona analiza wyników badań nie wykazała związku pomiędzy kwalifikacjami nauczycieli szkół ogólnodostępnych z zakresu pedagogiki specjalnej a rozumieniem przez nich pojęcia edukacja włączająca. Współczynnik kontyngencji $\mathrm{C}=0,129$ przy poziomie istotności statystycznej p $>0,05$. Oznacza to, że związek nie jest istotny statystycznie, a zatem nie ma związku pomiędzy badanymi zmiennymi.

\section{PODSUMOWANIE}

Analiza wyników badań pokazuje, że edukacja włączająca nadal jest pojęciem, które wymaga doprecyzowania i propagowania wśród nauczycieli. Pomimo swojej obecności zarówno w literaturze przedmiotu, jak i w praktyce edukacyjnej 
nadal budzi niezrozumienie, co utrudnia pełną realizację tego modelu nauczania. Debaty na poziomie akademickim oraz liczne publikacje naukowe nie mają przełożenia na wiedzę dotyczącą rozumienia inkluzji na najniższych szczeblach, a mianowicie w samej szkole ogólnodostępnej. Warto zatem zastanowić się w jaki sposób można upowszechniać wiedzę na temat tego typu nauczania, by edukacja włączająca mogła być realizowana w sposób świadomy, przemyślany i zgodny z jej założeniami.

Przeprowadzone badania skłaniają do następujących propozycji rozwiązań praktycznych możliwych do wprowadzenia w szkołach ogólnodostępnych.

\section{Edukacja nauczycieli w zakresie zasad inkluzji}

Działanie to zakłada prowadzenie seminariów, pogadanek oraz dostarczanie materiałów szkoleniowych dotyczących zasad realizacji edukacji włączającej w szkole ogólnodostępnej.

\section{Tutoring nauczycielski}

W ramach działań własnych nauczyciele mogą dzielić się swoją wiedzą dotyczącą realizacji włączającego modelu kształcenia. Nauczyciele z dłuższym stażem i bogatszym doświadczeniem mogą być tutorami dla młodszych i mniej doświadczonych kolegów. Obecność tutora może sprawić, że jego wiedza i doświadczenie okażą się cennym źródłem wsparcia w sytuacjach trudnych i pomogą przezwyciężyć obawy wynikające z braku doświadczenia w pracy w zróżnicowanej grupie uczniów.

\section{Banki dobrych praktyk}

Sukcesy poszczególnych szkół w zakresie realizowania edukacji włączającej mogą być inspiracją dla innych szkół i bazą do tworzenia kolejnych dobrych rozwiązań. Zatem warto, aby poszczególne szkoły upowszechniały swoje pomysły i osiągnięcia w tym zakresie poprzez tworzenie banków dobrych praktyk. W dzisiejszej dobie cyfryzacji i rozwoju portali społecznościowych możliwym rozwiązaniem służącym rozpowszechnianiu wiedzy na temat zasad i sposobów realizacji edukacji włączającej w codziennej praktyce mogą być grupy facebookowe, blogi i inne portale społecznościowe rozpowszechniające osiągnięcia różnych szkół w tym zakresie. Utworzone sieci stwarzałyby możliwość przedyskutowania problemów pojawiających się przy organizowaniu procesu włączania w szkołach ogólnodostępnych i mogłyby zapobiec powielaniu tych samych błędów oraz pomogłyby w znalezieniu konkretnych rozwiązań. Mogłyby też być źródłem inspiracji do działań na rzecz edukacji włączającej. 


\section{Szkolenia prowadzone przez kuratoria}

Rolą kuratora oświaty jest wspomaganie doskonalenia nauczycieli w celu przygotowania ich do realizacji procesu edukacyjnego, aby mógł on zaspokoić indywidualne potrzeby wszystkich uczniów. Toteż pomocne w propagowaniu edukacji włączającej mogą być również kuratoria oświaty. Instytucje te, oprócz działań monitorujących i nadzorujących pracę poszczególnych szkół, mogłyby organizować wyjazdowe szkolenia dla nauczycieli, konferencje tematyczne lub warsztaty dotyczące upowszechniania i rozumienia zasad inkluzji. Cykliczne organizowanie spotkań konsultacyjnych dla dyrektorów szkół pomogłoby we właściwej interpretacji nowelizowanych aktów prawa oświatowego. Ponadto dyrektorzy szkół mieliby możliwość zgłaszania i przedyskutowania bieżących problemów pojawiających się w trakcie realizacji edukacji włączającej w podległych im szkołach, co byłoby pomocne w szybkim ich rozwiązywaniu. Uzyskane podczas spotkań konsultacyjnych informacje byłyby przekazywane przez dyrektorów nauczycielom. Takie działania sprzyjałyby upowszechnianiu inkluzji i pomogły przybliżyć i lepiej zrozumieć zasady i organizację procesu edukacji włączającej wśród nauczycieli szkół ogólnodostępnych.

\section{Inicjatywy oddolne na rzecz promowania inkluzji}

Działania na rzecz włączania uczniów z niepełnosprawnościami do szkół ogólnodostępnych to inwestycja w kapitał społeczny, to budowanie społeczeństwa otwartego na różnorodność, to znoszenie barier i podziałów. Działania te mają zapobiegać izolacji, marginalizacji i wykluczaniu osób z niepełnosprawnościami bądź będących w niekorzystnej sytuacji materialnej, zdrowotnej czy społecznej na rzecz włączania ich w życie społeczne na równi z innymi i traktowanie ich jako pełnoprawnych członków społeczeństwa. Podstawowym warunkiem zrozumienia zasad edukacji włączającej jest akceptacja każdego ucznia bez względu na jego ograniczenia. Bez akceptacji i otwartości na drugiego człowieka trudno mówić o efektywnym włączaniu. Uprzedzenia, tendencje do marginalizowania potrzeb innych mogą utrudniać bądź uniemożliwiać realizację założeń edukacji włączającej. Zrozumieć edukację włączającą, to zrozumieć potrzeby drugiego człowieka, to umożliwić mu pełne uczestnictwo we wszystkich obszarach życia, to tworzenie przyjaznego środowiska w klasie i szkole, które będzie otwarte i umożliwi wspólne bycie razem i uczenie się. Bowiem wspólne uczenie się jest wstępem do życia we wspólnej przestrzeni publicznej. Inicjatywy oddolne prowadzone na rzecz promowania różnorodności jako wartości, a nie jako problemu czy zagrożenia pomogą w lepszym zrozumieniu zadań, jakie niesie za sobą system edukacji włączającej. 


\section{Bibliografia}

Al-Khamisy, D. (2013). Edukacja włączajq̨ca - edukacjq dialogu. Warszawa: Wyd. APS. Baylis, P. (2002). Edukacja włączająca. W: J. Bogucka, D. Żyro, T. Wejner, Od nauczania integracyjnego do szkoły równych szans. Warszawa: Centrum Metodyczne Pomocy Psychologiczno-Pedagogicznej.

Chodkowska, M., Kazanowski, Z. (2007). Socjopedagogiczne konteksty postaw nauczycieli wobec edukacji integracyjnej. Lublin: Wyd. UMCS.

Ćwirynkało, K., Żyta, A. (2015). Przekonania nauczycieli na temat edukacji włączającej uczniów ze specjalnymi potrzebami edukacyjnymi. Raport z badań. Szkoła Specjalna 4, s. 245-259. DOI: 10.5604/0137818x.1177729.

Delors, J. (1998). Edukacja - jest w niej ukryty skarb. Raport dla UNESCO Międzynarodowej Komisji do spraw Edukacji dla XXI wieku. Warszawa: Stowarzyszenie Oświatowców Polskich.

Doroszewski, W. (1985). Słownik języka polskiego. Warszawa: PWN.

Dudzikowa, M. (2013). Sprawcy lub/i ofiary działań pozornych w edukacji. Kraków: Impuls.

Dudzikowa, M. (2001). Mit o szkole jako miejscu „wszechstronnego rozwoju” ucznia. Eseje etnopedagogiczne. Kraków: Impuls.

Gajdzica, Z. (2013). Uczniowie i studenci z obszaru pogranicza wobec sytuacji osób niepełnosprawnych w środowisku lokalnym - nastawienia i opinie. Cieszyn: Stowarzyszenie wsparcia społecznego „Feniks”.

Gajdzica, Z. (2011). Opinie nauczycieli szkół ogólnodostępnych na temat edukacji włączającej uczniów z lekki upośledzeniem umysłowym w kontekście toczącej się reformy kształcenia specjalnego. W: Z. Gajdzica (red.), Uczeń z niepełnosprawnościq w szkole ogólnodostępnej (s. 56-79). Sosnowiec: Oficyna Wydawnicza Humanitas.

Głodkowska, J. (2010). Model kształcenia uczniów ze specjalnymi potrzebami edukacyjnymi różnice nie mogq dzielić. Założenia projektu Rozporządzenia MEN w sprawie warunków organizowania kształcenia, wychowania i opieki dla dzieci i młodzieży niepełnosprawnych oraz niedostosowanych społecznie w przedszkolach, szkołach i oddziałach ogólnodostępnych lub integracyjnych. Warszawa.

Grabowska, A., Gębicka-Zdanewicz, M. (red.). (2010). Szkoła równych szans. Uczeń niepełnosprawny w szkole ogólnodostępnej - budowanie systemu wsparcia i pomocy. Wrocław: Fundacja PROMYK SŁOŃCA.

Groenwald, M. (2011). Etyczne aspekty egzaminów szkolnych. Gdańsk: Wydawnictwo Uniwersytetu Gdańskiego.

Jachimczak, B. (2008). Gotowość nauczycieli szkół ogólnodostępnych do pracy z uczniem o specjalnych potrzebach edukacyjnych. W: I. Chrzanowska, B. Jachimczak (red.), Miejsce Innego we współczesnych naukach o wychowaniu - wyzwania praktyki. Łódź: Wydawnictwo Satori.

Konwencja Praw Osób Niepełnosprawnych ONZ. (2012). Pobrane z: http://www.unic. un.org.pl/dokumenty/Konwencja_Praw_Osob_Niepelnosprawnych.pdf.

Krause, A., Żyta, A., Nowosad, S. (2010). Normalizacja środowiska społecznego osób niepełnosprawnych intelektualnie. Toruń: Akapit.

Lechta, V. (2010). Pedagogika integracyjna kontra edukacja inkluzyjna (włączająca): 
podobieństwa i różnice. W: J. Wyczesany (red.), Krakowska pedagogika specjalna (s. 28-38). Kraków: Wyd. Naukowe Uniwersytetu Pedagogicznego.

Lutyński, J. (1990a). Nauka i polskie problemy. Komentarz socjologa. Warszawa: Państwowy Instytut Wydawniczy.

Lutyński, J. (1990b). System dogmatycznego autorytaryzmu i jego tendencje rozwojowe (ze szczególnym uwzględnieniem roli działań pozornych i ukrytych). W: J. Lutyński, Nauka i polskie problemy. Komentarz socjologa. Warszawa: Państwowy Instytut Wydawniczy.

Mika, S. (1987). Psychologia społeczna. Warszawa: PWN.

Skałbania, B., Babiarz, M. (2018). Edukacja włączająca jako przestrzeń dla rozwoju czy ryzyko wykluczenia i marginalizacji ucznia? Student Niepełnosprawny. Szkice i Rozprawy, 18(11), s. 17-27.

Skotnicka, B. (2017). Szkoła inkluzyjna jako organizacja ucząca się. W: Niepełnosprawność zagadnienia, problemy, rozwiq̨zania (s. 75-85). Warszawa: PFRON.

Szumski, G., Firkowska-Mankiewicz, A. (2010). Wokół edukacji włq̨czajq̨cej. Warszawa: Wydawnictwo APS.

Szymczak, M. (red.). (1987). Słownik języka polskiego. T. 2. Warszawa: Wydawnictwo PWN.

Turowski, J.(2001). Małe struktury społeczne. Lublin: Towarzystwo Naukowe KUL.

Żółkowska, T. (2009). Wybrane koncepcje edukacji integracyjnej. W: Z. Janiszewska-Nieścioruk (red.), Problemy edukacji integracyjnej dzieci i młodzieży z niepełnosprawnościq intelektualnq (s. 43-54). Kraków: Wydawnictwo Impuls. 